Research of features of manifestation of junior schoolchild's egotism in communication with peers

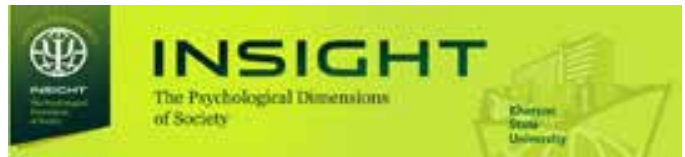

DOI: 10.32999/2663-970X/2020-4-5

Link article (Style APA): Radul I. H., Hundarenko O. V. \& Kowalczyk M. M. (2020). Research of features of manifestation of junior schoolchild's egotism in communication with peers. Insight: the psychological dimensions of society, 4, 73-89. DOI: 10.32999/2663-970X/2020-4-5

Link article (Style DSTU 8302: 2015): Radul, I. H., Hundarenko, O. V. \& Kowalczyk, M. M. Research of features of manifestation of junior schoolchild's egotism in communication with peers. Insight: the psychological dimensions of society, 2020, 4, 73-89. DOI: 10.32999/2663-970X/2020-4-5

UDC 159.922.73:316.454.52

\title{
Research of features of manifestation of junior schoolchild's egotism in communication with peers
}

\section{Дослідження особливостей прояву еготизму молодшого школяра у спілкуванні з ровесниками}

Received: April 04, 2020 Accepted: October 30, 2020

Radul Iryna Hennadiivna

Ph. D. in Psychology, Assistant Professor

Department of Practical Psychology

Volodymyr Vynnychenko Central Ukrainian

State Pedagogical University, Ukraine

cemruk@rambler.ru,

ORCID 0000-0002-3941-2518

Hundarenko Olena Volodymyrivna

Ph. D. in Germanic Philology

Department of English language and literature

Faculty of Humanities

University of Zilina, Slovakia

olena.hundarenko@fhv.uniza.sk,

ORCID 0000-0002-4642-7160

Kowalczyk Marlena Miroslawa

Doctor of humanities in the field of pedagogy, Assistant Professor

State University of Stefan Batory based in

Skierniewice, Poland

marlena.kowalczyk@gmail.com,

ORCID 0000-0003-3713-6350
Радул Ірина Геннадіївна

кандидат психологічних наук, доцент кафедра практичної психології

Центральноукраїнський державний педагогічний університет

імені Володимира Винниченка, Україна cemruk@rambler.ru, ORCID 0000-0002-3941-2518

Гундаренко Олена Володимирівна кандидат філологічних наук кафедра англійської мови та літератури факультет гуманітарних наук

Жилінський університет, Словаччина olena.hundarenko@fhv.uniza.sk, ORCID 0000-0002-4642-7160

Ковальчик Марлена Мірослава доктор гуманітарних наук у галузі педагогіки, доцент

Державний університет імені Стефан Баторій із Скерневіце, Польща marlena.kowalczyk@gmail.com, ORCID 0000-0003-3713-6350

\section{Abstract}

The purpose is to study empirically the level of egotism of junior schoolchild as a speech form of personal egocentrism during his/her interaction with

\section{Анотація}

Мета емпірично дослідити рівень еготизму молодшого школяра як мовленнєвої форми особистісного егоцентризму під час їх взаємодії з ровесниками.

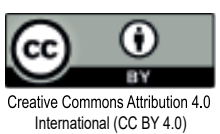




\section{Radul Iryna, Hundarenko Olena, Kowalczyk Marlena}

peers. Methods. Theoretical analysis and systematization of scientific resources on the problem of research was used in the study of egotism as a speech form of personal egocentrism. "Methods of studying egotism" has been used in order to study the phenomenon of egotism of dialogic speech and "Methods of studying egocentrism during interaction" by T. Pashukova and open uninvolved observation have been used in order to establish the relationship between egotism and the dominant form of personal egocentrism. Results. Personal egocentrism reflects a person's position in relation to the world around him/her, and is characterized by a focus on his/her position or own individual "Self". Personal egocentrism can manifest itself in human behavior, manner of reasoning, semantics of language in the form of egotism and retroflexion. In our work we define egotism as a person's desire to talk about him/herself, to remember personal advantages over others, thereby increasing his/her own significance. Through egotism there is a self-presentation of one's "Self". Conclusions. It was found that pupils of the first and second form show a high level of egotism, and third and fourth -form pupils showed an average one. That is, at the end of primary school age the desire to talk only about oneself, to present to the interlocutor only one's own person decreases. With age and the acquisition of socio-psychological competence, there is a tendency to reduce selfishness in primary school age as the desire of students to present their own person during a conversation with a communication partner. The control of the egotistical language and display of interest of the person acting as the partner on communication is shown. The dominant form of personal egocentrism of a junior schoolchild is the extroverted form.

Key words: dialogic speech, egotism, junior school child, extroverted form, introverted form, personal egocentrism, retroflexion, communication.

\section{Introduction}

Egocentrism as a psychological phenomenon has been the subject of study by many scholars of the pastand contemporaries.Particularattention was paid to the psychological nature and functions of egocentrism, age characteristics of egocentrism, positive and negative manifestations of the egocentrism and its types. The research was also aimed at studying conditions and mechanisms of overcoming egocentrism, features of prevention and correction
Методи. Під час вивчення еготизму як мовленнєвої форми особистісного егоцентризму використовувався теоретичний аналіз і систематизація наукових літературних джерел з проблеми дослідження. 3 метою дослідження феномену еготизму діалогічного мовлення - “Методика дослідження еготизму”, а з метою встановлення взаємозв'язку між еготизмом та домінуючою формою особистісного егоцентризму - "Методика дослідження егоцентризму під час взаємодії" Т. Пашукової та відкрите невключене спостереження. Результати. Особистісний егоцентризм відображає позицію людини по відношенню до оточуючого світу, характеризується зосередженістю на своїй позиції або власному індивідуальному “Я”. Особистісний егоцентризм може проявлятись у поведінці людини, манері міркування, семантиці мови у вигляді еготизму і ретрофлексії. В своїй роботі ми визначаємо еготизм - як прагнення людини розповісти про себе, згадати про свої переваги в противагу іншим, збільшуючи цим власну значущість. Через еготизм відбувається самопрезентація свого “Я”. Висновки. Встановлено, що учні перших та других класів демонструють високий рівень еготизму, а учні третіх та четвертих класів - середній. Тобто, під кінець молодшого шкільного віку знижується прагнення говорити лише про себе, презентувати співрозмовнику лише власну персону. 3 віком та набуттям соціально-психологічної компетенції, відбувається тенденція до зниження еготизму в молодшому шкільному віці як прагнення учнів презентувати власну персону під час розмови з партнером по спілкуванню. Виявляється контроль своєї еготичної мови та прояв зацікавленості особою, яка виступає партнером по спілкуванню. Домінуючою формою особистісного егоцентризму молодшого школяра є екстравертована форма.

Ключові слова: діалогічне мовлення, еготизм, молодший школяр, екстравертована форма, інтровертована форма, особистісний егоцентризм, ретрофлексія, спілкування.

\section{Вступ}

Егоцентризм, як психологічний феномен, був предметом вивчення багатьох науковців минулих часів, так і сучасників. Особлива увага приділялась психологічній природі та функціям егоцентризму, віковим особливостям розвитку егоцентризму, позитивним та негативним проявам егоцентризму та його видам. Дослідження були також спрямовані на вивчення умов та механізмів подолання егоцентризму, особливостям профілактики

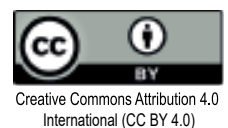


Research of features of manifestation of junior schoolchild's egotism in communication with peers

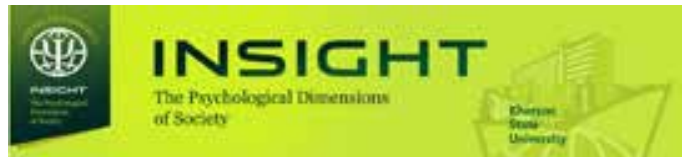

of egocentrism at different age stages of development.

The emergence of egocentrism, elucidation of its peculiarities of development at a different age stages, positive and negative manifestations of egocentrism have been the subject of study by the scientists from around the world, including Ukrainian psychologists. Cognitive, communicative and moral egocentrism are the most studied in psychology, while the less studied is personal egocentrism (Radul, 2019). However, the very concept of "egocentrism" is actively used to describe the quality or state of the individual and we can no longer talk about egocentrism in a broad sense, but indicate its type, namely personal egocentrism.

According to T. Pashukova, personal egocentrism can be both the main cause and consequence of cognitive and communicative egocentrism (Pashukova, 1998). K. Platonov considers this phenomenon as a quality of a personality, the main function of which is to assert one's own "I" (Platonov, 1984).

Through research, H. Schroeder divides egocentrism of cognitive processes and egocentrism as a property of the individual. According to him, the manifestations of personal egocentrism are associated with the process of communication and interaction with people. Among a number of factors that reduce personal egocentrism, he cites the following: reference of individuals, the importance of the situation and sociocentric orientation (Schroeder, 1981).

\section{Theoretical grounds of the problem}

The presence of fundamentally different points of view among a circle of national and international researchers on the concept of "egocentrism" allows us to talk about expanding the boundaries of its use in psychology. It should be noted that as a quality of personality egocentrism is a fixed attitude of man to his emotions, thoughts, ideas, goals, actions, qualities of character and temperament, etc. and in this case we are talking about personal egocentrism (Pashukova, 1998).

Personal egocentrism is a mechanism and phenomenon of interaction, communication and relationships between people (Bieńkowska et al., 2020; Popovych et al., 2020a; 2020b; та корекції егоцентризму на різних вікових етапах розвитку.

Виникнення егоцентризму, з'ясування його особливостей розвитку на різних вікових етапах, позитивних та негативних проявів егоцентризму були предметом вивчення вчених різних країн світу, у тому числі і українських психологів. Найбільш досліджуваним в психології є пізнавальний, комунікативний та моральний егоцентризм, водночас, менш досліджуваним $є$ особистісний егоцентризм (Радул, 2019). Однак, саме поняття “егоцентризм" активно використовується для характеристики якості чи стану особистості і мова не може вже йти про егоцентризм в широкому розумінні, а вказує на його вид, а саме особистісний егоцентризм.

На думку Т. Пашукової, особистісний егоцентризм може бути як основною причиною, так і наслідком пізнавального і комунікативного егоцентризму (Пашукова, 1998). К. Платонов розглядає даний феномен як якість особистості, основна функція якої полягає у ствердженні власного “Я” (Платонов,1984).

Завдяки здійсненим дослідженням, Х. Шрёдер розділяє егоцентризм пізнавальних процесів і егоцентризм як властивість особистості. На його думку, прояви особистісного егоцентризму пов'язані з процесом спілкування та взаємодії з людьми. Серед низки факторів, які знижують особистісний егоцентризм, він наводить такі: референтність осіб, значимість ситуації та соціоцентричну спрямованість (Шрьодер, 1981).

\section{Теоретичне обгрунтування проблеми}

Наявність принципово різних точок зору серед кола вітчизняних та зарубіжних дослідників щодо поняття “егоцентризм” дає змогу говорити про розширення меж його використання у психології. Зазначимо, що, як якість особистості, егоцентризм є фіксованою установкою людини на своїх хвилюваннях, думках, уявленнях, цілях, діях, якостях характеру i темпераменту тощо, і в цьому випадку мова вже йде однозначно про особистісний егоцентризм (Пашукова, 1998). У свою чергу, особистісний егоцентризм має певний емоційний прояв. У дорослих людей егоцентризм може 
Prokhorov et al., 2015). Personal egocentrism can significantly impede communication processes between people (Khmil \& Popovych, 2019; Silvia et al., 2009). In a broad sense, personal egocentrism is associated with position that is, the place that a person can occupy in various social structures. Personal egocentrism in communicative processes between people is expressed in the form of egotism and retroflexion (Radul, 2019).

Egotism is the desire to talk about oneself or one's relatives, emphasizing their connection with oneself. In speech, egotism is manifested in the mentioned by an individual his/her advantages, opportunities. The main purpose of such messages is to demonstrate own significance and self-awareness, which can lead to narcissism. For example, the following phrases may sound: "I am a stubborn person", "My husband does not understand me", "I always have my own position", etc. (Pashukova, 2012).

Retroflexion is a critical assessment of a person's behavior, attitude to him/herself as an object of reflection, analysis. In speech, retroflexion is manifested in the constant criticism of a person's own actions and behavior. For example, "I have to control my actions", "I'm ashamed of my behavior", "I'm a loser", etc. It is retroflexion that distracts the interlocutor from the person of the speaker, and therefore it is also considered one of the types of personal egocentrism. (Tsemriuk, 2006).

The concepts of "position" and "orientation" of the individual make it possible to describe the phenomena of egocentrism, which are different in scope and content. Regarding content, the phenomenology of egocentrism depends on what a person is fixed on: his thoughts, ideas, point of view or worries, state, selfassessment of others or worried about his/her status and attitude to him/herself. According to the number of spheres, properties, states, which are covered by egocentric phenomenology, it is possible to establish the extent of egocentrism of personality (Pashukova, 1998).

Considering that personal egocentrism is an expression of individual psychological characteristics of the individual, T. Pashukova distinguishes two forms: extroverted and introverted. проявлятись у формі саморефлексії, тобто аналізі безпосередньо власних якостей особистості, висловлювань, потягів та намірів, поведінки, емоцій і станів тощо (Цемрюк, 2006).

Особистісний егоцентризм виступає механізмом і феноменом взаємодії, спілкування та взаємовідносин людей (Bieńkowska et al., 2020; Popovych et al., 2020a; 2020b; Prokhorov et al., 2015). Особистісний егоцентризм суттєво може перешкоджати комунікативним процесам між людьми (Khmil, Popovych, 2019; Silvia et al., 2009). У широкому значенні особистісний егоцентризм пов'язаний 3 позицією - тобто, місцем, яке людина може займати у різного роду соціальних структурах. Особистісний егоцентризм у комунікативних процесах між людьми виражається у формі еготизму і ретрофлексії (Радул, 2019).

Еготизм - це прагнення говорити про себе чи своїх рідних, підкреслюючи їхній зв'язок із собою. В мовленні еготизм проявляється у згадувані людиною своїх переваг, можливостей. Основна мета таких повідомлень - це демонстрація власної значущості, власного самоусвідомлення, що може призвести до самозакоханості. Наприклад, можуть звучати такі фрази: "Я вперта людина", “Мій чоловік мене не розуміє”, “У мене завжди є власна позиція" і т. д. (Пашукова, 2012).

Ретрофлексія - це критична оцінка людиною своєї поведінки, ставлення до себе як до об'єкта міркувань, аналізу. В мовленні ретрофлексія проявляється в постійній критиці людиною власних вчинків, поведінки. Наприклад, "Я повинен управляти своїми вчинками", "Мені соромно за мою поведінку", "Я невдаха" і т. д. Саме ретрофлексія відволікає увагу співрозмовника на персону того, хто говорить, i тому теж прийнято її вважати одним із видом особистісного егоцентризму (Цемрюк, 2006).

Поняття “позиція" і “спрямованість” особистості дають можливість описати різні за об'ємом і змістом феномени егоцентризму. В змістовному плані феноменологія егоцентризму залежить від того, на чому людина фіксується: на своїх думках, уявленнях, точці зору чи на хвилюваннях, стані, на оцінці себе іншими чи переживає з приводу свого статусу і ставлення

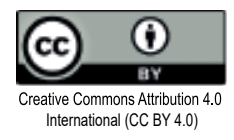


Research of features of manifestation of junior schoolchild's egotism in communication with peers

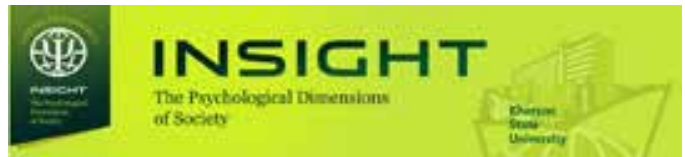

Introverted schizoids are characterized by isolation in communication, they get tired quickly, strive for self-isolation, get pleasure from being alone with their thoughts, worries. People around them have great difficulty communicating and interacting with them. The reason is that introverted schizoids are indifferent to the verbal and nonverbal signals of others during communication, they cannot use feedback effectively. Their introverted egocentrism is determined by the autistic state of their ego system (Tsemriuk, 2006).

Demonstrative communication with others is a characteristic of extroverted hysteroids. Unlike introverted schizoids, they accumulate their thoughts, views and worries on their interlocutors, while the balance of the "Self-Other" scale is disturbed and sharply deviates towards their "Self". Such people during communication get pleasure from the process of communication in the case when they think only about themselves, about their advantages over others. The process of communication in this case becomes onesided, because there is a focus on the person of the speaker. The speech in most cases is selfish, because it reflects a constant desire to talk only about himself. Hysteroid traits are often already inherent in a child at an early age.

Excessive self-centeredness prevents both schizoids and hysteroids from communicating effectively and tactfully with others. In both cases, such individuals are characterized by inadequately inflated self-esteem and the level of demands, unrealistic ideas about themselves, which complicate the development of social competence. Egocentrism disturbs theharmonious balance of the individual in communication and relationships with other people. Therefore, the detection of egocentrism in the early stages of ontogenesis deserves close attention of psychologists, teachers and parents. Also very important is the dialectical vision of egocentric phenomena in the developing personality. After all, the earlier a system of corrective educational influences is selected for a person with a high level of egocentrism, the more likely it is that all selected strategies slow down egocentric tendencies and thus increase the effectiveness of interaction with others. до себе. За кількістю сфер, властивостей, станів, які охоплюються егоцентричною феноменологією, можна встановити об'єм егоцентризму особистості (Пашукова, 1998).

Враховуючи те, що особистісний егоцентризм $\epsilon$ виразом індивідуально-психологічних особливостей особистості, Т. Пашукова виділяє дві його форми: екстравертовану та інтровертовану.

Інтровертованим шизоїдам властива замкненість у спілкуванні, вони швидко втомлюються, прагнуть до самоізоляції, отримують задоволення побути наодинці зі своїми думками, хвилюваннями. Оточуючі люди мають великі труднощі у спілкуванні та у взаємодії 3 ними. Причина полягає у тому, що інтровертовані шизоїди під час спілкування байдужі до вербальних і невербальних сигналів інших, не можуть ефективно використовувати зворотній зв'язок. Їх інтровертований егоцентризм детермінується аутичним станом їх его-системи (Цемрюк, 2006).

Демонстративність у спілкуванні з оточуючими властива екстравертованим істероїдам. Свої думки, погляди та хвилювання вони, на відміну від інтровертованих шизоїдів, нагромаджують на своїх співрозмовників, при цьому порушується баланс шкали "Я-Інший", різко відхиляється в бік свого “Я”. Такі люди під час спілкування отримують задоволення від процесу комунікації в тому випадку, коли вони ведуть міркування лише про себе, про свої переваги над іншими. Процес комунікації в даному випадку набуває одностороннього характеру, тому що відбувається центрація уваги на персоні того хто говорить. Мова у більшості випадків еготична, оскільки відображає постійне прагнення говорити лише про себе. Істероїдні риси досить часто вже притаманні дитині в ранньому віці.

Надмірна орієнтація на власну персону заважає шизоїдам та істероїдам ефективному спілкуванню й тактовному поводженню з оточенням. В обох випадках таким особистостям властива неадекватно завищена самооцінка i рівень домагань, нереальне уявлення про себе, які ускладнюють вироблення соціальної компетентності. Егоцентризм порушує гармонійну рівновагу особистості у комунікації 
The purpose. In national psychology, communication is considered as one of the types of speech activity. In this regard, we studied the speech form of a personality egocentrism - egotism. After all, it is through egotism that the self-presentation of one's "I" takes place. To study the speech form of personal egocentrism, the method of studying egotism was used, which allows to determine the magnitude and level of egotism of dialogic speech of the individual.

\section{Methods and methodology}

We used theoretical and empirical methods for the study, namely: theoretical analysis and systematization of scientific sources on the research problem; open unattended observation; conversation; psychodiagnostic methods.Toidentifythefeaturesofthephenomenon of egotism of dialogic speech, T. Pashukova's "Methodology of Egotism Research" was used. In order to establish the relationship between egotism and the dominant form of personal egocentrism, T. Pashukova's "Methodology of studying egocentrism during interaction" was used. Methods of mathematical statistics were also used (using Spearman's rank correlation rs).

The experiment involved 310 pupils of primary school ages from first to fourth grade (6-11 years). The method of studying egotism allows us to identify the magnitude and level of egotism of dialogic speech. It is based on the registration of verbal reactions of the subject under observation, and on their subsequent content analysis (Pashukova, 1998: 140-143). The study involves two children and an experimenter who records their conversation on a dictaphone or other technical devices. The children's task is to communicate with each other on any topic of their choice. With the consent of both interlocutors, the conversation is recorded on a dictaphone. Provided that the interlocutors do not agree to the recording, the researcher uses the technique of non-included systematic observation. He records the results in a protocol, where the total number of sentences uttered by the subject, as well as sentences in which he directly or indirectly spoke about him/herself, і взаєминах з іншими людьми. Тому пильної уваги психологів, педагогів та батьків заслуговує виявлення егоцентризму на ранніх етапах онтогенезу. Також дуже важливим $\epsilon$ діалектичне бачення егоцентричних феноменів у особистості, що розвивається. Адже чим раніше буде підібрана система корегуючих виховних впливів для особистості з високим рівнем прояву егоцентризму, тим вірогідніше, що всі підібрані стратегії пригальмують егоцентричні тенденції і тим самим підвищиться ефективність взаємодії з оточуючим людьми.

Мета. У вітчизняній психології спілкування розглядається як один із видів мовленнєвої діяльності. У зв'язку з цим нами досліджувалась мовленнєва форма егоцентризму особистості - еготизм. Адже саме через еготизм відбувається самопрезентація свого “Я”. Для вивчення мовленнєвої форми особистісного егоцентризму було використано методику дослідження еготизму, яка дозволяє визначити величину та рівень еготизму діалогічного мовлення особистості.

\section{Методи та методологія}

Для дослідження нами було використано теоретичні та емпіричні методи. А саме: теоретичний аналіз і систематизація наукових літературних джерел 3 проблеми дослідження; відкрите невключене спостереження; бесіда; психодіагностичні методи. Для виявлення особливостей феномену еготизму діалогічного мовлення - "Методика дослідження еготизму" Т. Пашукової, а з метою встановлення взаємозв'язку між еготизмом та домінуючою формою особистісного егоцентризму - “Методика дослідження егоцентризму під час взаємодії” Т. Пашукової. Використані також методи математичної статистики (використання рангової кореляції $\mathrm{r}_{\mathrm{s}}$ Спірмена).

В експерименті взяли участь 310 учнів молодшого шкільного віку з першого по четвертий клас (6-11 років). Методика дослідження еготизму дозволяє виявити величину та рівень еготизму діалогічного мовлення. Вона грунтується на реєстрації вербальних реакцій досліджуваного, за яким ведеться спостереження, та на подальшому їх контент аналізі(Пашукова1998: 140-143). У дослідженні 
Research of features of manifestation of junior schoolchild's egotism in communication with peers

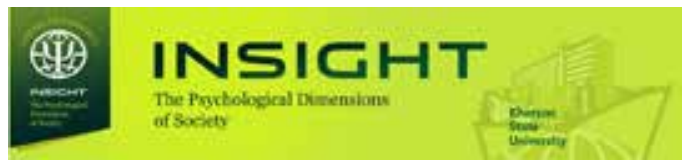

is marked with the help of signs. The research procedure can be completed when the total number of sentences uttered by a person whose language was studied for egotism is equal to hundred.

Analysis of the results of the study makes it possible to obtain a coefficient of egotism based on the ratio of egotism, which is the number of sentences in which the subject spoke about him/herself or people, events, animals, objects, emphasizing their connection with him/herself, and non-egotistical statements.

The method of studying egocentrism during interaction makes it possible to identify forms of personal egocentrism. This method is a variant of open, non-included, standardized observation of behavioral and verbal reactions of the subject.

In the process of study, the researcher records the number of behavioral and speech reactions that can be attributed to extroverted or introverted forms of egocentrism, as well as any non-egocentric acts of communication and interaction. Attention is also paid to nonverbal reactions: features of facial expressions, postures, gestures, tone of voice. It is important to monitor the emotions and the specifics of information exchange, the nature of interaction. Empirical referents of egocentrism and nonegocentric reactions are recorded in the study protocol, using observation tables.

Processing of results involves obtaining quantitative indicators of personal egocentrism of extroverted and introverted forms. For this purpose, in the protocol in each row of columns the total result of the noted speech and behavioral reactions is calculated. The obtained indicators of the sum are empirical referents of the extroverted and introverted form of personal egocentrism. Next, the individual index of egocentrism for each of the forms is clarified and it is compared which of them dominates, whether the non-egocentric form of expression and non-verbal behavior of the subject are dominant at all. The individual index of the extroverted and introverted forms of egocentrism is determined as follows: it is necessary to divide the sum by the total number of all reactions, for all three sums. The general indicator of personal egocentrism is a set бере участь по двоє дітей і експериментатор, який записує їх розмову на диктофон чи інші технічні засоби. Завдання дітей полягає у тому, щоб спілкуватися між собою на будьяку обрану ними тему. За згодою обох співрозмовників розмова записується на диктофон. За умови, якщо співрозмовники не погоджуються на запис, дослідник використовує прийом невключеного систематизованого спостереження. Він фіксує результати у протоколі, де за допомогою знаків відмічається загальна кількість речень, які промовив досліджуваний, а також речення, у яких він прямо чи опосередковано говорив про самого себе. Процедуру дослідження можна завершити, коли загальна кількість речень, промовлених особою, чию мову вивчали на еготизм, дорівнює сотні.

Аналіз результатів дослідження дає можливість отримати коефіцієнт еготизму на основі співвіднесення показника еготизму, яким $\epsilon$ кількість речень, у яких досліджуваний говорив про себе чи про людей, події, тварин, предмети, підкреслюючи при цьому їх зв'язок із собою, та нееготичних висловлювань.

Методика дослідження егоцентризму під час взаємодії дає змогу виявити форми особистісного егоцентризму. Дана методика $\epsilon$ варіантом відкритого, невключеного, стандартизованого спостереження за поведінковими та вербальними реакціями досліджуваного.

В процесі дослідження дослідник фіксує кількість поведінкових та мовленнєвих реакцій, які можна віднести до екстравертованої чи інтровертованої форми егоцентризму, а також будь-які неегоцентричні акти спілкування та взаємодії. Також звертається увага на невербальні реакції: особливості міміки, пози, жестів, тону голосу. Важливо стежити за емоціями та специфікою обміну інформацією, за характером взаємодії. Емпіричні референти егоцентризму і неегоцентричні реакції фіксуються у протоколі дослідження, при цьому використовуються таблиці спостережень.

Обробка результатів передбачає отримання кількісних показників особистісного егоцентризму екстравертованої та інтровертованої форми. 3 цією метою в протоколі у кожному рядку колонок підраховується сумарний 
of egocentrism of extroverted and introverted form.

\section{Results and discussions}

The first stage of the study was that we divided all individuals under study into pairs. The experimenter, with the consent of both partners, recorded their conversation on a dictaphone, in some cases using non-included systematic observation, the results of which were recorded in the study protocol. This observation involved fixing the content of the dialogue between the partners by the experimenter. The study protocol noted the total number of sentences spoken by a person under study, whose language is studied for egotism, as well as the number of sentences in which there is a self-presentation of one's own "I". According to the verbal reactions of the subjects, the coefficient of egotistical speech (the ratio of egotistical and nonegotistical expressions) was calculated, which correlates with the levels of egotism. The extent of the coefficient of egotism and the level of egotism is determined by the scale according to which egotism is divided into high, medium and low (Table 1).

A high level of egotism indicates that the individual pays excessive attention to his own "I", and is characterized by an increased level of selfreflection. Conversation with the interlocutor acquires a non-informative meaning, in its form it is more like a monologue than a dialogue. This leads to dissatisfaction with the communication partner.

The medium level indicates adequate egotistical self-presentation, which is necessary when communicating with a partner and building constructive interpersonal relationships for interaction.

The low level of egotism or its absence indicates a weak interest of the child in communication or that he is not attentive enough to his interlocutor. результат відмічених мовленнєвих та поведінкових реакцій. Отримані показники величини суми $\epsilon$ емпіричними референтами екстравертованої та інтровертованої форми особистісного егоцентризму. Далі з'ясовується індивідуальний індекс егоцентризму за кожною із форм і порівнюється, яка з них домінує, чи взагалі домінуючою є неегоцентрична форма висловлювання та невербальна поведінка досліджуваного. Індивідуальний індекс екстравертованої та інтровертованої форми егоцентризму визначається таким чином: необхідно суму поділити на загальну кількість усіх реакцій. Загальний показник особистісного егоцентризму є сукупністю егоцентризму екстравертованої та інтровертованої форми.

\section{Результати та дискусії}

Перший етап дослідженні полягав у тому, що ми розподілили усіх досліджуваних по парам. Експериментатор за згодою обох партнерів записував їх розмову на диктофон, у деяких випадках використовувалося невключене систематизоване спостереження, результати якого фіксувалися в протоколі дослідження. Таке спостереження передбачало фіксацію експериментатором змісту діалогу, який відбувається між партнерами. У протоколі дослідження відмічалася загальна кількість речень, яку промовив досліджуваний, чию мову вивчають на еготизм, а також кількість речень, в яких відбувається самопрезентація власного "Я". За вербальними реакціями досліджуваних підраховувався коефіцієнт еготичного мовлення (співвідношення еготичних та нееготичних висловлювань), який співвідноситься 3 рівнями еготизму. Величина коефіцієнта еготизму та рівень еготизму визначається за шкалою, згідно з якою еготизм поділяється на високий, середній та низький (табл. 1).

Високий рівень еготизму вказує на те, що особистість приділяє надмірну увагу власному

Table 1. Scale for assessing the level of egotism

Таблиця 1. Шкала оцінювання рівня еготизму

\begin{tabular}{|c|c|}
\hline $\begin{array}{l}\text { The value of the coefficient of egotism } \\
\text { Величина коефіцієнта еготизму }\end{array}$ & $\begin{array}{c}\text { The level of egotism } \\
\text { Рівень еготизму }\end{array}$ \\
\hline from/від .41 to/до 1.00 & High/Високий \\
\hline from/від .11 to/до .40 & Medium/Середній \\
\hline from/від .01 to/до .10 & Low/Низький \\
\hline
\end{tabular}


Research of features of manifestation of junior schoolchild's egotism in communication with peers

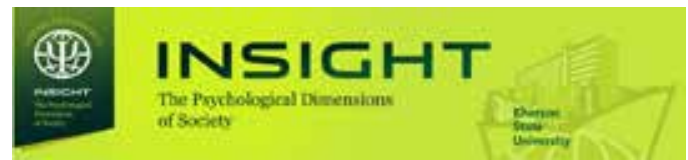

The results of the study of egotism in first-form pupils are presented in Figure 1.

The value of the coefficients of egotism in first-form pupils varies from .2 to 1.0 at $d=.8$. It was found that in communication with peers, most of the first-form pupils show a high level of egotism $72.0 \%$, i.e. seek to demonstrate them and express themselves through egotistical speech. Also, 28.0\% of respondents showed a medium level of egotism. Individuals under study with a low level of egotism were not identified. The dominance of a high level of egotism in the first-form pupils is a manifestation of the age peculiarity of the studied phenomenon.

Statistics on first-form pupils show that during the dialogue (in oral speech) with peers, the individuals under study shows a high level of egotistical sentences $(\bar{\chi}=.91)$. The extent of egotism in first-class pupils with peers corresponds to a high level. Our observations show that in the case of a high level of egotism in the "I-messages" of theindividual there is aviolation of the sequence of the message structure. This later begins to irritate the interlocutor and complicate the dialogue between communication partners, or it does not happen at all.

The study of egotism in second-form pupils has shown the same tendency for a high level of egotism as in the previous age group. This can be seen in the bar chart shown in Figure 2.

The value of the coefficients of egotism in second-graders varies from .09 to 1.0 at $\mathrm{d}=.91$. $64.0 \%$ of respondents show an appeal to their

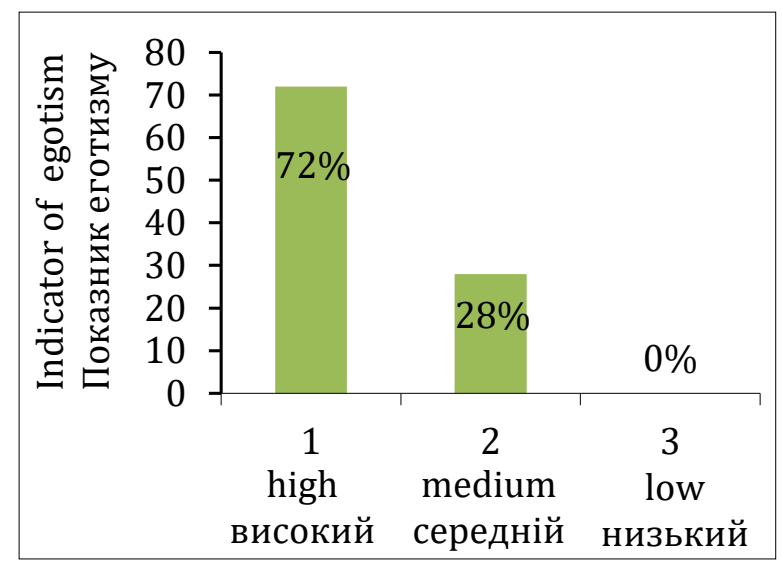

Fig. 1. Distribution Indicator of egotism in first-form pupils Рис. 1. Розподіл еготизму в учнів першого класу
“Я”, характеризується підвищеним рівнем саморефлексії. Розмова 3 співрозмовником набуває неінформаційного змісту, за своєю формою вона більш нагадує монолог, ніж діалог. Це призводить до невдоволення партнера по спілкуванню.

Середній рівень свідчить про адекватну еготичну самопрезентацію, яка $є$ необхідною під час спілкування з партнером та побудови конструктивних міжособистісних стосунків для взаємодії.

Низький рівень еготизму або його відсутність говорить про слабку зацікавленість дитини у спілкуванні або про те, що вона не досить уважна до свого співрозмовника.

Результати дослідження еготизму в учнів перших класів представлено на рис. 1.

Величина коефіцієнтів еготизму в учнів перших класів варіюється від 0.2 до 1.0 при $\mathrm{d}=0,8$. Встановлено, що у спілкуванні з ровесниками більшість досліджуваних перших класів демонструють високий рівень еготизму $72.0 \%$, тобто прагнуть через еготичне мовлення продемонструвати себе та самовиразитися. Також $28.0 \%$ досліджуваних продемонструвало середній рівень еготизму. Досліджуваних 3 низьким рівнем еготизму не виявлено. Домінування високого рівня еготизму у досліджуваних-першокласників $\epsilon$ проявом вікової особливості досліджуваного феномену.

Статистичні дані по учням перших класів показують, що під час діалогу (в усному

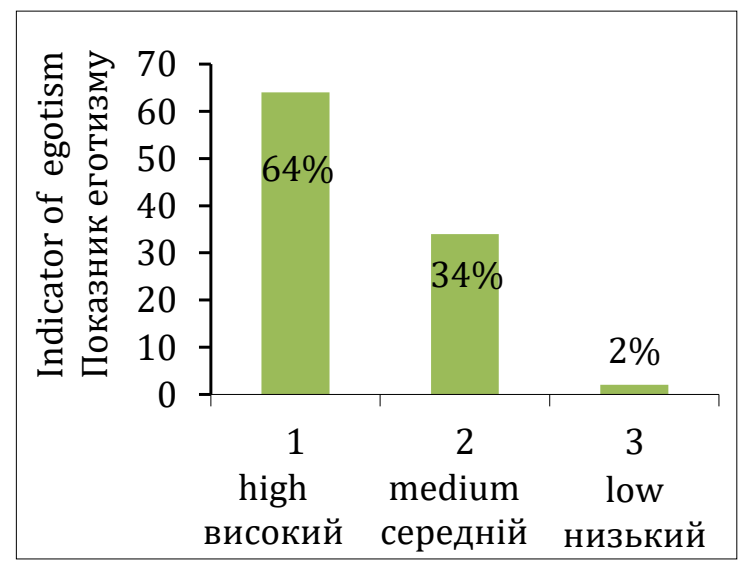

Fig. 2. Distribution of egotism in second-form pupils Рис. 2. Розподіл еготизму в учнів другого класу 
"I" when communicating with peers. The average level of egotism is shown by $34.0 \%$, low by $2.0 \%$. The results of the study showed that a high level of egotism gradually decreases due to an increase of individuals under study with a medium level of egotism and the emergence of a group of subjects with a low level of egotism. The greatest indicator of egotism in oral speech is manifested in secondform pupils $(\bar{\chi}=.87)$. Thus, the extent of egotism, which is revealed during the dialogue of secondform pupils with peers, corresponds to a high level.

The changes that have taken place in the distribution of egotism levels in the third grade are presented in Figure 3.

The value of the coefficients of egotism in thirdform pupils varies from .08 to 1.0 at $d=.92$. In third-form pupils, in contrast to first- and secondgraders, the medium level of egotism prevails; it was demonstrated by $53.0 \%$ of respondents. These results indicate that when communicating with peers, pupils of this age are more focused on the content of what their interlocutor says. $44.0 \%$ of those who took part in our study have a desire to talk only about themselves and only 3.0\% have a low level of egotism. Statistics on third-form pupils show that during the dialogue with peers, the subjects show the largest number of egotistical sentences $(\bar{\chi}=.24)$. The extent of egotism, which is revealed during the dialogue of third-form pupils with peers, corresponds to the medium level.

According to our study, in the fourth grade changes in the distribution of egotism are quite small, as can be seen from Figure 4 .

The value of the coefficients of egotism in fourthform pupils varies from .14 to 1.0 at $d=.86$. Most fourth-graders show a medium level of egotism when communicating with the interlocutor (53\%). A significant part of the respondents $(44.0 \%)$ pay excessive attention to their own "I" in communication. Only $3.0 \%$ of pupils have a low level of dialectical egotism. Statistics on fourthform pupils show that during the dialogue with peers, the subjects show the largest number of egotistical sentences $(\bar{\chi}=.29)$. The extent of egotism of fourth-form pupils corresponds to the medium level.

Thus, first and second class pupils show a high level of egotism, and third and fourth graders show мовленні) з ровесниками досліджувані демонструють високий рівень еготичних речень $(\bar{\chi}=.91)$. Величина еготизму у першокласників з ровесниками відповідає високому рівню. Наші спостереження показують, що у випадку високого рівня еготизму в "Я-повідомленнях" індивіда спостерігається порушення послідовності структури повідомлення, що згодом починає дратувати співрозмовника і утруднювати діалог між партнерами по спілкуванню або ж він взагалі не відбувається.

Дослідження еготизму в учнів других класів виявило таку ж саму тенденцію стосовно високого рівня еготизму, що і у попередній віковій групі. Це видно на гістограмі, що зображена на рисунку 2.

Величина коефіцієнтів еготизму в учнів других класів варіюється від .09 до 1.0 при $\mathrm{d}=.91$. Зверненість до свого “Я" під час спілкування з ровесниками демонструють $64.0 \%$ досліджуваних, середній рівень еготизму проявляють $34.0 \%$, низький - $2.0 \%$. Результати дослідження показали, що високий рівень еготизму поступово знижується за рахунок збільшення досліджуваних 3 середнім рівнем еготизму та появи групи досліджуваних $з$ низьким рівнем еготизму. Найбільший показник еготизму в усному мовленні проявляється в учнів других класів ( $\bar{\chi}=.87)$.Таким чином, величина еготизму, яка виявлена під час діалогу другокласників з ровесниками, відповідає високому рівню.

Зміни, які відбулися у розподілі рівнів еготизму в третьому класі, представлені на рисунку 3.

Величина коефіцієнтів еготизму в учнів третіх класів варіюється від .08 до 1.0 при $\mathrm{d}=.92$. У третьокласників, на відміну від учнів перших та других класів, переважає середній рівень еготизму, його продемонструвало $53.0 \%$ досліджуваних. Ці результати вказують на те, що під час спілкування з ровесниками учні цього віку більше орієнтуються на зміст того, що говорить їх співрозмовник. Прагнення говорити лише про себе мають $44 \%$ тих, хто прийняв участь в нашому досліджені, і лише $3.0 \%$ мають низький рівень еготизму. Статистичні дані по учням третіх класів показують, що під час діалогу з ровесниками досліджувані 
Research of features of manifestation of junior schoolchild's egotism in communication with peers

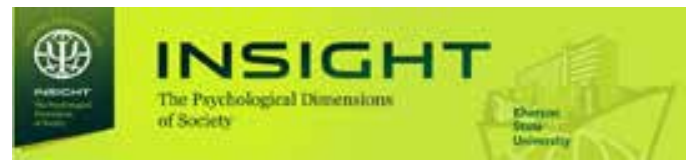

a medium. That is, at the end of primary school age (third graders) children's desire to talk only about them, to present to the interlocutor only their own person decreases during the conversation with peers. They feel more comfortable in the system of interpersonal relationships; use techniques and methods of communication more successfully.

It is worth noting that our monitoring of primary school children with different levels of egotism revealed some psychological features of pupils. Thus, pupils with a high level of egotism during the dialogue showed a more obsessive self-presentation of themselves or their relatives compared to pupils with a medium and low level of egotism. They deliberately embellished their words or invented the events they told about, became the initiators in the choice of communication. During the dialogue, students with a high level of egotism emphasized their accomplishments, thus increasing their importance.

Respondents with a medium level showed a sincere interest in communication, positive emotions, were open and friendly with their interlocutors. Pupils with a low level of egotism were less open and relaxed during the dialogue than students with a medium and a high level of egotism. They did not show activity and initiative in expressing opinions, and communication for them was formal.

The purpose of our study was also to identify the interconnection between the dominant form of personal egocentrism of the junior school child

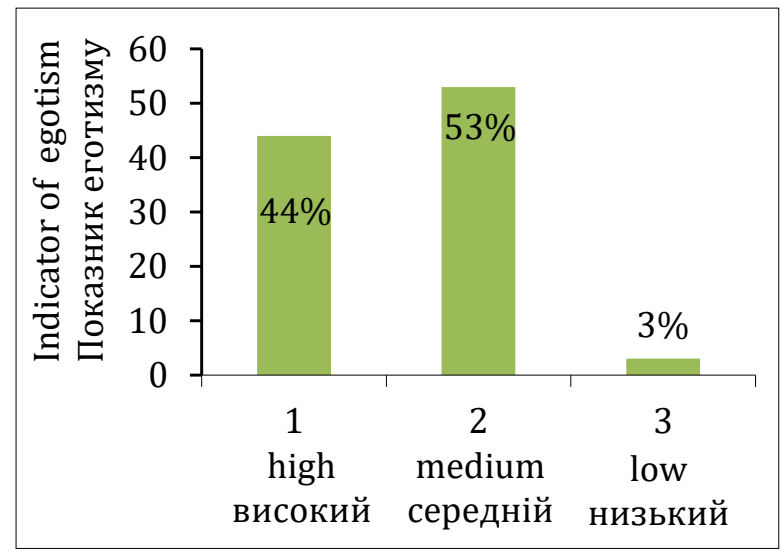

Fig. 3. Distribution of egotism in third-form pupils

Рис. 3. Розподіл еготизму в учнів третього класу демонструють найбільшу кількість еготичних речень $(\bar{\chi}=.24)$.Величина еготизму, яка виявлена під час діалогу третьокласників з ровесниками, відповідає середньому рівню.

За даними нашого дослідження, у четвертих класах зміни у розподілі еготизму досить незначні, що видно з рис. 4.

Величина коефіцієнтів еготизму в учнів четвертих класів варіюється від .14 до 1.0 при $\mathrm{d}=.86$. Більшість учнів четвертих класів під час спілкування зі співрозмовником демонструють середній рівень еготизму (53.0\%). Значна частина досліджуваних (44.0\%) надмірну увагу у спілкуванні приділяє власному “Я”, і лише 3\% учнів мають низький рівень еготизму діалогічного мовлення. Статистичні дані по учням четвертих класів показують, що під час діалогу з ровесниками досліджувані демонструють найбільшу кількість еготичних речень $(\bar{\chi}=.29)$.Величина еготизму учнів четвертих класів відповідає середньому рівню.

Таким чином, учні перших та других класів демонструють високий рівень еготизму, а учні третіх та четвертих класів - середній. Тобто, під кінець молодшого шкільного віку (третьокласники) у дітей під час розмови з ровесниками знижується прагнення говорити лише про себе, презентувати співрозмовнику лише власну персону, вони комфортніше почувають себе в системі міжособистісних стосунків, успішніше використовують прийоми і способи спілкування.

Варто зауважити, що наші спостереження за учнями молодшого шкільного віку з різними

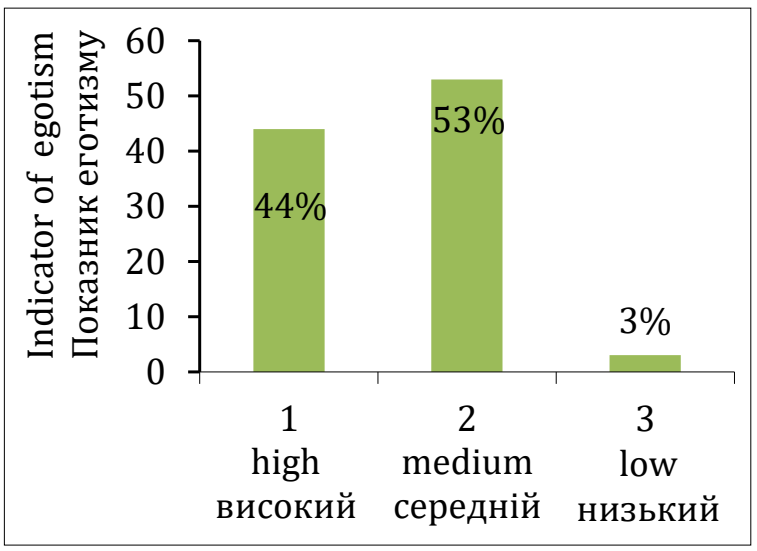

Fig. 4. Distribution of egotism in fourth-form pupils

Рис. 4. Розподіл еготизму в учнів четвертого класу 


\section{Radul Iryna, Hundarenko Olena, Kowalczyk Marlena}

and egotism in interaction and communication with peers. Analysis of the results of our observation of the extroverted and introverted form of egocentrism of primary school children during joint activities with peers showed that the dominant in the first grades is a strong degree of extroverted form of egocentrism, i.e. when interacting with peers most pupils ignore the position and feelings of his/her partner.

Most of subjects with a strong extroverted form of egocentrism are in the second grade, which indicates the inability of these pupils to work effectively with peers. Among thirdgraders, there is also a clear predominance of subjects with a strong degree of expression of the extroverted form of egocentrism. Fourthgraders tend to increase the number of subjects with a strong degree of egocentrism, which negatively affects the interaction of subjects. Thus, the results of a study of the severity of extroverted and introverted forms of personal egocentrism in primary school age showed that a strong degree of expression of the extroverted form of egocentrism prevails among younger pupils of different ages. That is, when interacting with peers, the junior school child tends to demonstrate him/herself and his/her achievements, to impose hi/her point of view on the participants of the interaction, without taking into account the thoughts, plans and wishes of their partners.

In our study, we hypothesized that the indicator of the extroverted form of personal egocentrism absorbs egotism as a person's desire to talk about him/her. Therefore, we assume that subjects with a high level of egotism have a strong degree of manifestation of the extroverted form of egocentrism and this connection is inverse.

In our study, we used the normal distribution of the sample, which was pre-arranged for comparison. The sample was tested by N. Plokhinsky $t_{a}=2.7516<=3 ; t_{e}=.8443<=3$ and E. Pustilnikov $\mathrm{A}_{\text {emp }}=.674<\mathrm{A}_{\text {cre }}=.7169 \mathrm{E}_{\mathrm{emp}}=$ $=.4136<\mathrm{E}_{\mathrm{cr}}=2.2737$.

To test our assumption, we performed a correlation analysis of the data, which found that there is a reliable interconnection between egotism and the extroverted form of egocentrism. That is, subjects with a high level of egotism, as a rule, show a strong degree of manifestation of the extroverted рівнями еготизму виявили деякі психологічні особливості школярів. Так учні з високим рівнем еготизму під час діалогу проявили більш нав'язливу самопрезентацію себе або своїх рідних порівняно з учнями з середнім та низьким рівнем розвитку еготизму. Навмисне прикрашали свої слова або вигадували події, про які вони розповідали, ставали ініціаторами у виборі спілкування. Під час діалогу, учні з високим рівнем еготизму підкреслюючи свої заслуги, підвищували тим самим свою значущість.

Досліджувані з середнім рівнем виявляли щиру зацікавленість у спілкуванні, позитивні емоції, були відвертими та дружелюбними з своїми співрозмовниками. Учні з низьким рівнем еготизму були менш відвертими та розкутими під час діалогу, ніж учні із середнім та високим рівнем еготизму, не проявляли активності та ініціативності у висловленні думок, спілкування для них мало формальний характер.

Метою нашого дослідження також було виявлення взаємозв'язку між домінуючою формою особистісного егоцентризму молодшого школяра та еготизмом під час взаємодії та спілкування з ровесниками. Аналіз результатів нашого спостереження за екстравертованою та інтровертованою формою егоцентризму молодшого школяра під час виконання спільної діяльності з ровесниками показав, що домінуючим у перших класах $\epsilon$ сильний ступінь прояву екстравертованої форми егоцентризму, тобто під час взаємодії з ровесниками більшість учнів не зважає на позицію та почуття свого партнера.

Найбільше досліджуваних з сильно вираженою екстравертованою формою егоцентризму у другому класі, що свідчить про невміння цих учнів ефективно співпрацювати з ровесниками. Серед учнів третіх класів також спостерігається явне переважання досліджуваних 3 сильним ступенем вираження екстравертованої форми егоцентризму. В учнів четвертого класу спостерігається тенденція до збільшення кількості досліджуваних з сильним ступенем вираження егоцентризму, що негативно позначається на взаємодії досліджуваних. Отже, результати дослідження ступенів вираженості екстравертованої та інтровертованої форми особистісного егоцентризму в молодшому шкільному віці

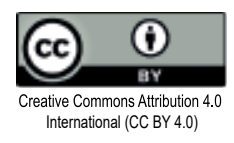


Research of features of manifestation of junior schoolchild's egotism in communication with peers

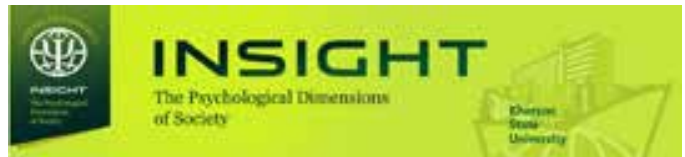

form of egocentrism. Spearman's rank correlation coefficient $r_{\text {в емп }}=.71$ (critical value $r_{\text {s кр }}=.33-.43$ for $\mathrm{p}=.05$ and $\mathrm{p}=.01$, respectively) $r_{s: \kappa p}=\left\{\begin{array}{l}0,33(\rho \leq 0,05) \\ 0,43(\rho \leq 0,01)\end{array} \quad r_{\text {s емп }}>r_{\text {s кр }}\right.$ for $\mathrm{n}=310$. In other words, the correlation between egotism and the extroverted form reaches the level of statistical significance, or differs to a great extent from 0 . School children with a medium level of egotism have a medium degree of extroverted form of egocentrism. Subjects with a low level of egotism are characterized by a low degree of manifestation of the extroverted form of egocentrism. Thus, the correlation between egotism and the extroverted form reaches the level of statistical significance.

The results of the research allow us to conclude that the level of egotism in the speech communication of junior school children is high. In addition, the study of the egotism's dynamics of younger pupils in the process of their interaction with peers showed that a high level of egotism and its stability is reduced by age.

Personal egocentrism in interpersonal interaction and communication of junior school children is mostly extroverted. The obtained results allow us to assume that the subjects of primary school age with a medium level of egotism have more favorable conditions for the development of their communicative abilities to decentrate. They spend more time with adults (parents) and, as a result, acquire communication skills faster. Thanks to this experience and interaction with seniors, they are also quicker to learn patterns of socially acceptable behavior, feel more comfortable in the system of interpersonal relationships, more successfully use techniques and methods of communication with people of different ages.

The results of our study indicate the need for further study of egotism in adolescents and senior pupils in order to study the patterns and dynamics of the transition from egotism to the style of integration and willingness to communicate effectively with peers.

\section{Conclusions}

1. Egotism is a phenomenon that manifests itself only in the youngest age group of primary показали, що серед молодших школярів різного віку переважає сильний ступінь вираження екстравертованої форми егоцентризму. Тобто, під час взаємодії з ровесниками молодшому школяру властиво демонструвати себе та свої досягнення, нав'язувати учасникам взаємодії свою точку зору, не враховуючи при цьому думок, планів та побажань своїх партнерів.

У нашому дослідженні ми зробили припущення, що показник екстравертованої форми особистісного егоцентризму вбирає в себе i еготизм як прагнення людини говорити про себе. Тому ми припускаємо, що досліджувані 3 високим рівнем еготизму мають сильний ступінь прояву екстравертованої форми егоцентризму і цей зв'язок $є$ зворотнім.

Під час нашого дослідження ми використовували нормальний розподіл за вибіркою, яка заздалегідь була упорядкована з метою порівняння. Вибірка перевірена за Н. Плохинським $\mathrm{t}_{\mathrm{a}}=2.7516<=3 ; \mathrm{t}_{\mathrm{e}}=.8443<=3$ та E. Пустильниковим $\mathrm{A}_{\text {емп }}=.674<\mathrm{A}_{\text {кр }}=.7169$; $\mathrm{E}_{\text {емп }}=.4136<\mathrm{E}_{\text {кр }}=2.2737$.

Для перевірки нашого припущення ми здійснили кореляційний аналіз даних, у результаті якого встановлено, що між еготизмом та екстравертованою формою егоцентризму існує достовірний зв'язок. Тобто, досліджувані 3 високим рівнем еготизму, як правило, демонструють сильний ступінь прояву екстравертованої форми егоцентризму. Коефіцієнт рангової кореляції Спірмена $r_{\text {s емп }}=0.71$ (критичне значення $r_{\mathrm{s} \text { кр }}=0.33-0.43$ для $\mathrm{p}=0.05$ та $\mathrm{p}=0,01$ відпо-

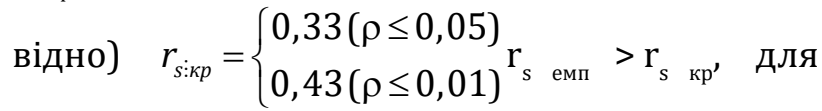
$\mathrm{n}=310$. Іншими словами, кореляція між еготизмом та екстравертованою формою досягає рівня статистичної значимості або значимо відрізняється від 0.

Це пояснює, що високому рівню еготизму відповідає сильний ступінь прояву екстравертованої форми егоцентризму.

В учнів з середнім рівнем еготизму спостерігається середній ступінь екстравертованої форми егоцентризму. Досліджувані з низьким рівнем еготизму характеризуються слабким ступенем прояву екстравертованої форми егоцентризму. Отже, кореляція між еготизмом

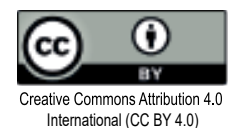




\section{Radul Iryna, Hundarenko Olena, Kowalczyk Marlena}

school age, in school children of first and second grades. Egotism is expressed in the tendency to monologue speech and excessive desire to talk only about him/her and demonstrate own superiority over other people.

2. With age and the acquisition of sociopsychological competence, there is a tendency to reduce egotism in primary school age as the desire of pupils to present their own person during a conversation with a communication partner. There is a tendency in third and fourth graders to reduce egotism. This is manifested in a decrease of the desire to talk only about themselves and in an increase of interest of the person who acts as a communication partner.

3. At the end of primary school age, our subjects were characterized by control of their egotistical language and interest in the person who acts as a communication partner.

4. The dominant form of personal egocentrism of a junior school child is the extroverted one.

5. A reliable correlation has been established between egotism and the extroverted form of egocentrism.

6. The presented results of the research will help psychologists, teachers and parents to determine the inadequacy of egocentric development trends of younger pupils timely. Also, with the help of an individual approach and changes in educational influences, corrective and preventive measures, it will be possible to correct the personal development of junior school children.

The study does not cover all aspects of the problem of egotism of a junior school child. The obtained results can become a basis for in-depth study of the phenomenon of egotism and features of its manifestations in the educational activities of pupils not only of primary school age, but also in adolescence.

\section{References}

Bieńkowska, I., Polok, K. \& Sutkowski, A. (2020). Making language teachers creative; teaching English in elementary mainstream schools with integration classes. The New Educational Review, 59(1), 103-115. DOI: 10.15804/tner.2020.59.1.08

Chambers, J. R., Windsehirt, P. D. \& Suls J. (2003). Egocentrism, event frequency, and comparative optimism: when what happens frequently is "more та екстравертованою формою досягає рівня статистичної значимості.

Результати дослідження дозволяють зробити висновок про те, що рівень еготизму у мовленнєвому спілкуванні молодших школярів високий. Крім того, вивчення динаміки еготизму у молодших школярів в процесі їх взаємодії з ровесниками показало, що високий рівень еготизму і його стійкість знижується шляхом вікового дозрівання.

Особистісний егоцентризм у міжособистісній взаємодії та спілкуванні молодших школярів переважно екстравертований. Отримані результати дозволяють зробити припущення про те, що у досліджуваних молодшого шкільного віку 3 середнім рівнем еготизму склалися більш сприятливі умови для розвитку їх комунікативних здібностей до децентрації. Вони більше часу проводять з дорослими (батьками), і як наслідок швидше набувають комунікативних умінь. Завдяки такому досвіду та взаємодії зі старшими, вони швидше також засвоюють зразки соціально схваленої поведінки, комфортніше почувають себе в системі міжособистісних стосунків, успішніше використовують прийоми і способи спілкування з людьми різних вікових груп.

Результати нашого дослідження вказують на необхідність подальшого вивчення еготизму у підлітків та старшокласників з метою вивчення закономірностей та динаміки переходу від еготизму до стилю інтеграції та готовності до ефективного спілкування з ровесниками.

\section{Висновок}

1. Еготизм є феноменом, що проявляється лише в наймолодшій віковій групі молодшого шкільного віку, в учнів перших і других класів. Еготизм виражається у схильності до монологічного мовлення і надмірному бажанні говорити лише про себе та демонструвати свої переваги над іншими людьми.

2. 3 віком та набуттям соціально-психологічної компетенції відбувається тенденція до зниження еготизму в молодшому шкільному віці як прагнення учнів презентувати власну персону під час розмови 3 партнером по спілкуванню. В учнів третього і четвертого класів має місце тенденція до зниження еготизму, що проявляється у зменшенні прагнення говорити лише про 
Research of features of manifestation of junior schoolchild's egotism in communication with peers

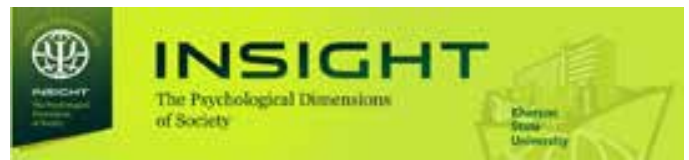

likely to happen to me". Personality and social psychology bulletin, 804-825.

Enright, R., Lapsley, D. \& Shukla. D. (1979). Adolescent egocentrism in early and late adolescence. Adolescence, 14, 687-695.

Khmil, V. V., \& Popovych, I. S. (2019). Philosophical and Psychological Dimensions of Social Expectations of Personality. Anthropological Measurements of Philosophical Research, 16, 55-65. DOI: 10.15802/ampr.v0i16.187540

Maratsos, M. P.(1973). Non-egocentric communication abilities in preschool children. Child development, 44, 89-92.

Pashukova, T. I. (2012). Egotism of presenters and participants of TV programs. Psychology of dialogue and the human world. Collection of scientific works of Kirovohrad State Pedagogical University by Volodymyr Vynnychenko, 2, 85-97.

Pashukova, T. I. (1998). Egocentrism in adolescentc. A textbook for students, school psychologists and teachers. Moscow: Institute of Practical Psychology, 1998.

Piaget, J. (1994). Speech and thinking of the child: transl. from French. Moscow: Pedagogika, 1994.

Platonov, K. K. (1984). A short dictionary of the system of psychological concepts. Moscow: Higher school, 1984.

Popovych, I., Kononenko, O., Kononenko, A., Stynska, V., Kravets, N., Piletska, L. \& Blynova, O. (2020a). Research of the Relationship between Existential Anxiety and the Sense of Personality's Existence. Revista Inclusiones, Vol: 7 num Especial, 41-59.

Popovych, I., Laliuk, G., Aleksieieva, M., Popovych, A., Bondarenko, V., Kovtun, 0. \& Tsiuniak, O. (2020b). Sociocultural metrics of the personal paradigm of orphans' upbringing in pedagogical theory and practice of Ukraine. Revista Inclusiones, Vol: 7 num 3, 343-356.

Prokhorov, A. O., Yusupov, M. G. \& Plokhikh, V. V. (2015). Cognitive States in the Process of Students' Intellectual Activity. The New Educational Review, 41(3), 263-274. DOI: 10.15804/tner.2015.41. 3.21 .

Radul, I.H. (2019). Research of egocentrism of children's speech in psychology. Insight: psychological dimensions of society, 2. pp. 52-57. DOI: 1032999/2663970X/2019-2-7

Schroeder, H. (1981). To the Differential-psychological study of social decentration. Psychological states: Experimental and applied psychology. Leningrad: Leningrad Publishing House. University, 10, 125-131.

Silvia, P. J., Robert, A. H. \& Templin, J. L. (2009). Are the sources of interest the same for everyone? Using multilevel mixture models to explore себе і в збільшенні зацікавленості особою, яка виступає партнером по спілкуванню.

3. Наприкінці молодшого шкільного віку для наших досліджуваних характерним виявився контроль своєї еготичної мови та прояв зацікавленості особою, яка виступає партнером по спілкуванню.

4. Домінуючою формою особистісного егоцентризму молодшого школяра $€$ екстравертована форма.

5. Між еготизмом та екстравертованою формою егоцентризму встановлено достовірний кореляційний зв'язок.

6. Представлені результати дослідження допоможуть психологам, вчителям та батькам своєчасно визначати неадекватність егоцентричних тенденцій розвитку у молодших школярів. За допомогою індивідуального підходу та змін у виховних впливах, корекційних та профілактичних заходах здійснювати корекцію особистісного розвитку молодших школярів.

Проведене дослідження не вичерпує всіх аспектів проблеми еготизму молодшого школяра. Отримані результати можуть стати підгрунтям для поглибленого вивчення феномену еготизму та особливостей його проявів у навчальній діяльності учнів не лише молодшого шкільного віку, але і підліткового та юнацького.

\section{Список використаних джерел}

Bieńkowska I., Polok K., Sutkowski, A. Making language teachers creative; teaching English in elementary mainstream schools with integration classes. The New Educational Review, (2020), № 59(1), P. 103-115. DOI: $10.15804 /$ tner.2020.59.1.08

Chambers J. R., Windsehirt P. D, Suls J. Egocentrism, event frequency, and comparative optimism: when what happens frequently is "more likely to happen to me". Personality and social psychology bulletin. 2003. P. 804-825.

Enright R., Lapsley D., Shukla D. Adolescent egocentrism in early and late adolescence. Adolescence. 1979. №14. P. 687-695.

Khmil V. V., Popovych, I. S. Philosophical and Psychological Dimensions of Social Expectations of Personality. Anthropological Measurements of Philosophical Research, 2019, № 16, P. 55-65. DOI: $10.15802 /$ ampr.v0i16.187540

Maratsos M. P. Non-egocentric communication abilities in preschool children. Child development. 1973, № 44. P. 89-92.

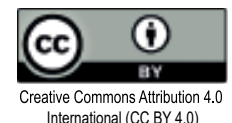




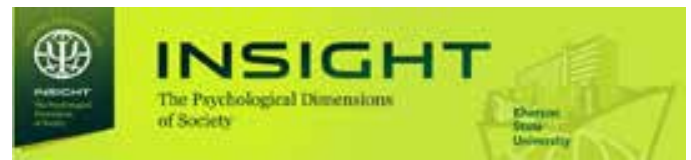

individual differences in appraisal structures. Cognition and Emotion, 23(7), 1389-1406. DOI: $10.1080 / 02699930902850528$.

Tsemriuk, I. H. (2006). Types of egocentrism of personality. Scientific journal of National Pedagogical Dragomanov University, 10(34), 18-22.

\section{Radul Iryna, Hundarenko Olena, Kowalczyk Marlena}

Пашукова Т. И. Эготизм у ведущих и участников телепередач. Психологія діалогу і світ людини. Збірник наукових праць Кіровоградського державного педагогічного університету ім. Володимира Винниченка: Т. 2. Кіровоград : Ф0-П Александрова М. В., 2012. С. 85-97.

Пашукова Т. И. Эгоцентризм в подростковом июношеском возрасте: причины ивозможности коррекции. М.: Институт практической психологии, 1998. 160с.

Пиаже Ж. Речь и мышление ребенка. М.: Педагогика, 1994. 528c.

Платонов К.К. Краткий словарь системы психологических понятий. М.: Высшая школа, 1984. $174 \mathrm{c}$.

Popovych I. Kononenko O., Kononenko A., Stynska V., Kravets N., Piletska L., Blynova O. Research of the Relationship between Existential Anxiety and the Sense of Personality's Existence. Revista Inclusiones, 2020a, Vol: 7 num Especial, P. 41-59.

Popovych I., Laliuk G., Aleksieieva M., Popovych A., Bondarenko V., Kovtun O., Tsiuniak O. Sociocultural metrics of the personal paradigm of orphans' upbringing in pedagogical theory and practice of Ukraine. Revista Inclusiones, 2020b, Vol: 7 num 3, P. 343-356.

Prokhorov A. O., Yusupov M. G., Plokhikh V. V. Cognitive States in the Process of Students' Intellectual Activity. The New Educational Review, 2015, № 41(3), P. 263-274. DOI: 10.15804/tner.2015.41.3.21.

Радул I. Г. Дослідження егоцентризму дитячого мовлення в психології. Інсайт: психологічні виміри суспільства, 2019. Вип. 2. С. 52-57.

Шрёдер Х. К. Дифференциально-психологическому изучению социальной децентрации. Психологические состояния: Экспериментальная и прикладная психология. Л.: ЛГИ, 1981. Вып. 10. С. 125-131.

Silvia P. J., Robert A. H., Templin, J. L. Are the sources of interest the same for everyone? Using multilevel mixture models to explore individual differences in appraisal structures. Cognition and Emotion, 2009, № 23(7), P. 1389-1406. DOI: $10.1080 / 02699930902850528$.

Цемрюк I. Г. Види та типи егоцентризму особистості. Науковий часопис НПУ імені М. П. Драгоманова. Серія № 12. Психологічні науки: Зб. наукових праць. К.: НПУ імені М. П. Драгоманова, 2006, № 10(34). C. 18-22. 